\title{
PENGARUH KESELAMATAN KERJA DAN KESEHATAN KERJA TERHADAP KINERJA KARYAWAN PT. ANGKASA KARGO UNIT REGULATED AGENT TERMINAL KARGO BANDARA SOEKARNO - HATTA TAHUN 2019
}

\author{
* Yulianti Keke ${ }^{1}$, Noel Gontu L. Tobing ${ }^{2}$, Irza Tanjung ${ }^{3}$ \\ ${ }^{1,2,3}$ Institut Transpoortasi dan Logistik Trisakti, Jakarta, Indonesia
}

*Email Korespondensi:

yuliakeke@gmail.com

\section{ARTIKEL INFORMASI}

Diterima:

27 Juni 2021

Direvisi:

15 Juli 2021

Dipublikasi:

25 Juli 2021

\begin{abstract}
ABSTRAK
PT. Angkasa Pura Kargo berfokus pada layanan di bidang jasa operator terminal kargo, pelayanan kargo dan pos udara serta pengembangan prasarana dan sarana terminal kargo di semua bandara yang berada di wilayah barat Indonesia. Angkasa Pura Kargo beroperasi di sejumlah bandar udara Indonesia yang dikelola oleh Angkasa Pura II (Persero). Angkasa Pura Kargo juga memiliki unit bisnis di bidang pemeriksaan keamanan terhadap kargo dan pos (Regulated Agent). Penelitian ini bertujuan untuk menganalisis dan mengetahui seberapa besar pengaruh Keselamatan Kerja dan Kesehatan Kerja terhadap Kinerja Karyawan . Penelitian ini menggunakan Penelitian Kuantitatif dengan menggunakan sampel Accidental sebanyak 38 responden di Unit regulated agent PT. Angkasa Pura Kargo . Berdasarkan Analisis yang telah di lakukan menunjukan bahwa terdapat pengaruh yang positif dan signifikan Keselamatan Kerja Terhadap Kinerja Karyawan, selain itu hasil analisis ini menunjukan bahwa terdapat pengaruh yang signifikan dan positif oleh Kesehatan Kerja terhadap Kinerja Karyawan, dan terdapat pengaruh yang signifikan dan positif oleh Keselamatan Kerja dan Kesehatan Kerja secara simultan terhadap Kinerja Karyawan.
\end{abstract}

Kata Kunci: Keselamatan Kerja, Kesehatan Kerja, Kinerja Karyawan

\section{PENDAHULUAN}

Angkasa Pura Kago merupakan anak usaha strategis dari PT. Angkasa Pura II (Persero) selaku pengelola bandara di wilayah Indonesia Barat yang diperkenalkan pada 7 Oktober 2016. Angkasa Pura Kargo diperkenalkan berbarengan dengan unit usaha lain yaitu PT. Angkasa Pura Propertindo. Angkasa Pura Kargo berfokus pada layanan di bidang jasa operator terminal kargo, pelayanan kargo dan pos udara serta pengembangan prasarana dan sarana terminal kargo. Angkasa Pura Kargo beroperasi di sejumlah bandar udara 
Indonesia yang dikelola oleh Angkasa Pura II (Persero). Angkasa Pura Kargo juga memiliki unit bisnis di bidang pemeriksaan keamanan terhadap kargo dan pos (Regulated Agent). Regulated Agent adalah badan hukum Indonesia yang melakukan kegiatan usaha dengan badan usaha angkutan udara yang memperoleh izin dari Dirjen Perhubungan untuk melaksanakan pemeriksaan keamanan terhadap kargo dan pos.

Pemeriksaan kargo (Pemeriksaan Keamanan Kargo) adalah prosedur pemeriksaan adalah prosedur pemeriksaan untuk mencegah terangkutnya bahan peledak (explosive) dan bahan berbahaya (dangerous substances) dalam kiriman kargo dan pos yang akan diangkut dengan angkutan pesawat udara sipil. Regulated Agent mulai diberlakukan pada tanggal 16 Mei 2011 dan Regulated Agent Angkasa Pura Kargo mulai ada pada tahun 2012 dibawah naungan Angkasa Pura Solusi yang kemudian diambil alih oleh Angkasa Pura Kargo pada tahun 2016 berdasarkan izin Direktorat Jenderal Transportasi Udara Nomor AU/9392/DKP.926/VII/2011. Salah satu unsur penting dalam manajemen organisasi ataupun perusahaan adalah sumber daya manusia (SDM) atau karyawan.

Sumber daya manusia sebagai penggerak atau motor dalam manajemen organisasi ataupun perusahaan . Pemamfaatan sumber daya manusia yang baik tentu sangat berpengaruh pada perusahaan dengan kinerja sumber daya manusia yang maksimal tentu akan menguntungkan perusahaan. Peran sumber daya manusia merupakan modal dasar dalam menentukan tujuan perusahaan. Tanpa peran sumber daya manusia, kegiatan dalam perusahaan tidak akan berjalan dengan baik. Manusia selalu berperan aktif dan dominan dalam setiap kegiatan organisasi,karena manusia menjadi perencana, pelaku dan penentu terwujudnya tujuan organisasi (Hasibuan, 2019). Keselamatan dan kesehatan kerja adalah keselamatan yang berhubungan dengan aktivitas kerja manusia baik pada industri,manufactur dan konstruksi yang melibatkan mesin,peralatan,penanganan material,pesawat uap,bejana bertekanan,alat kerja bahan baku dan proses pengolahannya,landasan tempat kerja dan lingkungannya serta cara-cara melakukan pekerjaan,maupun industri jasa yang melibatkan peralatan pembersih gedung,sarana transportasi dll (Mangkunegara, 2017).

Keselamatan dan kesehatan kerja merupakan aspek penting dari sumber daya manusia. Perusahaan berperan penting dalam menjaga keselamatan dan kesehatan kerja sumber daya manusia (SDM) atau karyawan. Seperti yang kita ketahui transportasi udara sangat mengedepankan keselamatan sebagai nilai jual yang paling utama dari jasa transportasi ini tentunya dengan ditunjang dengan sarana dan prasarana yang layak dan sumber daya manusia yang mampu dengan baik dalam pengoprasiannya. Namun fakta yang ada di lapangan banyak ditemukan karyawan yang tidak menggunakan peralatan pelindung dan ditemukan beberapa alat keselamatan cukup tua yang sudah tidak layak.

Oleh sebab itu penyediaan peralatan pelindung yang mencukupi dan memadai serta melakukan pergantian pada alat keselamatan yang sudah tidak layak atau melebihi batas usia pakai sangat diperlukan demi menghindari kecelakaan baik berupa incident maupun accident. Beberapa peralatan pelindung yang harus digunakan dalam pekerjan khusus seperti helm pelindung, sarung tangan pelindung,masker, sepatu pelindung serta rompi. Kecelakaan bisa terjadi karena adanya faktor-faktor bahaya. Faktor-faktor ini yang harus dihilangkan untuk mencegah kecelakaan dengan memperbaiki sarana dan prasarana serta merubah metode kerja yang tidak aman. Namun kesadaran karyawan dalam menggunakan peralatan pelindung diri yang masih minim dan beranggapan menggunakan peralatan pelindung menambah beban kerja serta menambah waktu dalam penggunaannya.

Ada pula yang merasa tidak nyaman dalam menggunakan alat pelindung diri dan pelatihan yang diberikan kurang dipahami oleh karyawan. Standar keselamatan serta kesehatan kerja yang di abaikan sering menyebabkan kecelakaan pada karyawan. Tentu kecelakaan menimbulkan kerugian baik secara ekonomis maupun secara tingkat kesehatan karyawan. Kesehatan kerja merupakan hal yang harus diperhatikan karyawan demi menciptakan lingkungan kerja yang sehat ,aman serta bebas dari pencemaran lingkungan. Akan tetapi kesadaran akan hal ini belum maksimal dan dapat berpengaruh pada kinerja karyawan itu sendiri sehingga dapat memperbesar peluang kecelakaan yang pada akhirnya mengurangi produktivitas dan efiensi karyawan di perusahaan. Sumber atau potensi yang dapat menciderai dapat diketahui melalui aspek identifikasi bahaya baik dalam bentuk kondisi kelainan mental atau fisik yang disebabkan karena atau dari ataupun bertambah buruk karena situasi atau proses kegiatan kerja.

Formulir identifikasi bahaya telah diterapkan oleh PT.Angkasa Pura Kargo demi mengetahui seluruh potensi yang ada di lingkungan kerja. Akan tetapi , karyawan tidak memahami tata cara pengisian formulir identifikasi bahaya dan potensi bahaya yang ada sering kali lalai teridentifikasi oleh karyawan. Sehingga upaya perusahaan dalam membantu keselamatan dan kesehatan kerja karyawan kurang terlakasana dengan efektif. Kesehatan kerja sebagai suatu kondisi kesehatan yang bertujuan agar masyarakat pekerja memperoleh derajat kesehatan yang setinggi-tingginya,baik jasmani, rohani maupun sosial dengan pencegahan dan pengobatan 
terhadap penyakit atau gangguan kesehatan yang disebabkan oleh pekerjaan dan lingkungan kerja maupun penyakit umum. Salah satu pencegahan terhadap penyakit jasmani yang dapat dilakukan oleh perusahaan yaitu pemeriksaan kesehatan rutin terhadap karyawan serta perlunya mengadakan senam olahraga pagi bagi karyawan sebagai pencegahan terhadap penyakit (Erickson, 2014). Oleh karena itu keselamatan dan kesehatan karyawan adalah hal penting yang harus diperhatikan perusahaan guna mendapatkan kinerja karyawan yang baik.

\section{KAJIAN PUSTAKA}

Menurut (Mangkunegara, 2013), keselamatan kerja menunjukkan pada kondisi yang aman atau selamat dari penderitaan, kerusakan atau kerugian di tempat kerja. Menurut (Moenir, 2018) Dimensi keselamatan kerja adalah:

1) Lingkungan kerja secara fisik Secara fisik, upaya-upaya yang perlu dilakukan perusahaan untuk meningkatkan keselamatan kerja adalah:

a) Penempatan benda atau barang dilakukan dengan diberi tanda-tanda, batas-batas, dan peringatan yang cukup.

b) Penyediaan perlengkapan yang mampu untuk digunakan sebagai alat pencegahan, pertolongan dan perlindungan. Perlengkapan pencegahan misalnya: alat pencegahan kebakaran, pintu darurat, kursi pelontar bagi penerbangan pesawat tempur, pertolongan apabila terjadi kecelakaan seperti: alat-alat PPPK, perahu penolong di setiap kapal besar, tabung oksigen, ambulance dan sebainya.

2) Lingkungan sosial psikologis Sedangkan jaminan kecelakaan kerja secara psikologis dapat dilihat pada aturan organisasi sepanjang mengenai berbagai jaminan organisasi atas pegawai atau pekerja yang meliputi:

a. Aturan mengenai ketertiban organisasi dan atau pekerjaan hendaknya diberlakukan secara merata kepada semua pegawai tanpa kecuali.

b. Masalah-masalah seperti itulah yang sering menjadi sebab utama kegagalan pegawai termasuk para eksekutif dalam pekerjaan

c. Perawatan dan pemeliharaan asuransi terhadap para pegawai yang melakukan pekerjaan berbahaya dan resiko, yang kemungkinan terjadi kecelakaan kerja yang sangat besar. Asuransi meliputi jenis dan tingkat penderitaan yang dialami pada kecelakaan. Adanya asuransi jelas menimbulkan ketenangan pegawai dalam bekerja.

Menurut (Moenir, 2018) yang dimaksud kesehatan kerja adalah suatu usaha dan keadaan yang memungkinkan seseorang mempertahankan kondisis kesehatannya dalam pekerjaan. Menurut(Manullang, 2008), Dimensi kesehatan kerja yang meliputi:

1) Lingkungan kerja secara medis Dalam hal ini lingkungan kerja secara medis dapat dilihat dari sikap perusahaan dalam menengani hal-hal sebagai berikut:

a. Kebersihan lingkungan kerja

b. Suhu udara dan ventilasi ditempat kerja

c. Sistem pembuangan sampah dan industri

2) Sarana kesehatan tenaga kerja Upaya-upaya dari perusahaan untuk meningkatkan kesehatan dari tenaga kerjanya. Hal ini dapat dilihat dari penyediaan air bersih dan sarana kamar mandi. Menurut (Kasmir, 2016) berpendapat bahwa kinerja adalah hasil kerja dan prilaku kerja yang telah dicapai dalam menyelesaikan tugas-tugas dan tanggung jawab yang diberikan dalam suatu periode tertentu.

Dalam penelitian ini, penulis menggunakan teori menurut (Mangkunegara, 2017) sebagai dimensi variabel kinerja (Y), yaitu:

a. Kualitas kerja

b. Kuantitas kerja

c. Pelaksanaan tugas

d. Tanggung jawab Berdasarkan uraian masalah dan teori yang telah dibahas diatas maka penulis membuat hipotesis untuk variabel yang di teliti.

Dimana untuk memberikan jawaban sementara atau perkiraan pemecahaan masalah adalah sebagai berikut :

H1 : Keselamatan kerja berpengaruh signifikan terhadap Kinerja karyawan.

H2 : Kesehatan kerja berpengaruh signifikan terhadap Kinerja karyawan. 
H3 : Keselamatan kerja dan Kesehatan kerja berpengaruh signifikan secara bersama-sama terhadap Kinerja karyawan.

\section{METODE}

Penelitian ini dilakukan di perusahaan PT. Angkasa Pura Kargo unit regulated agent. penelitian ini dilakukan dengan cara menyebarkan kuesioner secara langsung kepada para karyawan. hal ini dilakukan untuk meminta keterangan dan informasi yang dimiliki dan di ketahui serta yang di alami selama ini. Dalam hal ini yang menjadi populasi adalah karyawan PT. Angkasa Pura Kargo unit regulated agent berjumlah 60 orang dengan sampel 38 orang menggunakan rumus Slovin dan teknik sampling yang digunakan adalah penggunaan sampel accidental.

Kuesioner yang akan di bagikan akan menggunakan metode analisa skala Likert sebagai berikut :

Tabel 1. Penilaian Skala Likert

\begin{tabular}{ll}
\hline Penilaian & Skor \\
\hline Sangat Setuju & 5 \\
\hline Setuju & 4 \\
\hline Ragu - Ragu & 3 \\
\hline Tidak Setuju & 2 \\
\hline Sangat Tidak Setuju & 1 \\
\hline \multicolumn{2}{l}{ Sumber : Sugiyono (2017:93) }
\end{tabular}

Dalam penelitian ini penulis menggunakan beberapa teknik analisis data dengan melakukan perhitungan untuk menjawab rumusan masalah serta untuk menguji hipotesis yang telah diajukan. Yaitu :

1. Analisis Regresi Linier Berganda : analisis regresi dilakukan untuk mempelajari pengaruh variabel bebas (independen) terhadap variabel tak bebas (Dependen).

2. Analisis Korelasi Berganda :Koefisisen korelasi berganda dilakukan untuk mengetahui kuat atau tidaknya pengaruh antara variabel X1, variabel X2 dan variabel Y.

3. Koefisien Determinasi : Untuk mengetahui seberapa besar persentase sumbangan pengaruh yang diberikan variabel independen terhadap dependen digunakan analisis koefisien determinasi (penentu).

4. Uji Hipotesis :

a. Uji Parsial (Uji t) : Uji t (t-test) melakukan pengujian terhadap koefisien regresi secara parsial, pengujian ini dilakukan untuk mengetahui signifikansi peran secara parsial antara variabel independen terhadap variabel dependen.

b. Uji Simultan (Uji F) : Uji F melakukan pengujian terhadap koefisien regresi secara simultan, pengujian ini dilakukan untuk mengetahui signifikansi peran secara simultan antar variabel independen terhadap variabel dependen

\section{HASIL DAN PEMBAHASAN}

Dari hasil pengujian regresi maka ditemukan:

Tabel 2. Coefficients

\begin{tabular}{|c|c|c|c|c|c|c|}
\hline \multicolumn{4}{|c|}{ UnstandardizedCoefficients } & \multicolumn{3}{|c|}{ StandardizedCoefficients } \\
\hline Mode & & $\mathrm{B}$ & Std.Error & Beta & $\mathrm{t}$ & Sig \\
\hline 1 & (Constant) & 2.362 & 3.298 & & 0.716 & 0.479 \\
\hline & Keselamatan Kerja (X1) & 0.448 & 0.159 & 0.398 & 2.817 & 0.008 \\
\hline & Kesehatan Kerja (X2) & 0.405 & 0.118 & 0.486 & 3.441 & 0.002 \\
\hline
\end{tabular}

Dependent Variable: KINERJA KARYAWAN (Y)

Sumber : Data telah diolah penulis menggunakan 
Pada Regresi Linear Berganda

$\mathrm{Y}=2,362+0,448 \mathrm{X} 1+0,405 \mathrm{X} 2$

Dimana :

$\mathrm{Y}=$ Kinerja Karyawan

$\mathrm{X} 1=$ Keselamatan Kerja

$\mathrm{X} 2$ = Kesehatan Kerja

Persamaan regresi linear berganda tersebut mengandung arti bahwa setiap kenaikan skor penerapan pada variabel X1 (Keselamatan Kerja) sebesar 0,448 maka akan diikuti meningkatnya Y (Kinerja ). Setiap terjadi kenaikan 1 unit skor untuk variabel X2 (kesehatankerja) sebesar 0,405 akan diikuti dengan meningkatnya Y (Kinerja Karyawan). Dari persamaan diatas maka nilai Y akan menjadi 2,362.

\begin{tabular}{|c|c|c|c|c|}
\hline \multicolumn{5}{|c|}{ Tabel 3. R Square } \\
\hline Model & $\mathrm{R}$ & R Square & AdjustedR Square & Std. Error of the Estimate \\
\hline 1 & $.824^{\mathrm{a}}$ & 0.678 & 0.660 & 2.697 \\
\hline
\end{tabular}

a. Predictors: (Constant), Kesehatan Kerja (X2), Keselamatan Kerja (X1)

Sumber : Data diolah penulis menggunakan SPSS 25

Berdasarkan hasil perhitungan diketahui koefisien kolerasi sebesar 0,824 menyatakan bahwa ketiga variabel tersebut memiliki hubungan yang sangat kuat dan linear positif sensuai dengan tabel tingkat koreasi dan kekuatan hubungan.

$\mathrm{R}=0,824$

$\mathrm{KD}=\mathrm{R}^{2} \times 100 \%$

$=(0,824)^{2} \times 100 \%$

$=0,678 \times 100 \%$

$=67,8 \%$

Dapat diketahui koefisien determinasi atau (R2) sebesar 0,678. Hasil ini berarti variabel independen (Keselamatan Kerja dan Kesehatan Kerja) dapat menjelaskan sebesar 67,8\% terhadap variabel dependen yaitu Kinerja Karyawan sedangkan sisaya 32,2\% dijelaskanoleh variabel lain yang tidak disertakan dalam model ini.

Tabel 4. Coefficients Keselamatan Kerja (X1)

\begin{tabular}{ccccccc}
\hline \multicolumn{2}{c}{ UnstandardizedCoefficients } & \multicolumn{3}{c}{ StandardizedCoefficients } \\
\hline Model & B & Std.Error & Beta & $\mathrm{t}$ & Sig \\
\hline 1 & (Constant) & 4.113 & 3.717 & & 1.106 & 0.276 \\
\hline \multicolumn{2}{l}{ Keselamatan Kerja (X1) } & 0.850 & 0.123 & 0.755 & 6.899 & 0.000 \\
\hline
\end{tabular}

a. Independent Variable: Keselamatan Kerja (X1)

Sumber : Data diolah penulis menggunakan SPSS 25

$$
\begin{aligned}
& \mathrm{Dk}=\mathrm{n}-\mathrm{k} \mathrm{Dk}=38-2 \\
& \mathrm{Dk}=36 \\
& \mathrm{Dk}=1,688
\end{aligned}
$$

Pada tabel diatas nilai thitung untuk Keselamatan Kerja sebesar 9.336 sedangkan nilai ttabel sebesar 1,688. Maka dapat diketahui thitung $6.889>$ ttabel 1,688 dan nilai signifikan 0,000 lebih kecil dari 0,05. Sehingga hipotesis yang berbunyi terdapat pengaruh positif dan signifikan antar Keselamatan Kerja dan

\begin{tabular}{|c|c|c|c|c|c|c|}
\hline \multicolumn{4}{|c|}{ UnstandardizedCoefficients } & \multicolumn{3}{|c|}{ StandardizedCoefficients } \\
\hline Mode & & B & Std.Error & Beta & $\mathrm{t}$ & Sig \\
\hline & (Constant) & 7.486 & 3.005 & & 2.491 & 0.017 \\
\hline
\end{tabular}
Kinerja Karyawan.

Tabel 5. Coefficients Kesehatan Kerja (X2) 


\begin{tabular}{llllll}
\hline Kesehatan Kerja (X2) & 0.648 & 0.087 & 0.778 & 7.430 & 0.000
\end{tabular}

a. Independent Variable: Kesehatan Kerja (X2)

Sumber : Data diolah penulis menggunakan SPSS 25

$$
\begin{aligned}
& \mathrm{Dk}=\mathrm{n}-\mathrm{k} \mathrm{Dk}=38-2 \\
& \mathrm{Dk}=36 \\
& \mathrm{Dk}=1,688
\end{aligned}
$$

Pada tabel diatas nilai thitung untuk Keselamatan Kerja sebesar 7.486 sedangkan nilai ttabel sebesar 2.491. Maka dapat diketahui thitung $7.486>$ ttabel 2.491 dan nilai signifikan 0,000 lebih kecil dari 0,05. Sehingga hipotesis yang berbunyi terdapat pengaruh positif dan signifikan antar Kesehatan Kerja dan

\begin{tabular}{|c|c|c|c|c|c|}
\hline Model & Sum of Squares & df & Mean Square & $\mathrm{F}$ & Sig. \\
\hline 1 Regression & 536.798 & 2 & 268.399 & 36.886 & $.000^{\circ}$ \\
\hline Residual & 254.675 & 35 & 7.276 & & \\
\hline Total & 791.474 & 37 & & & \\
\hline
\end{tabular}
Kinerja Karyawan.

Tabel 6. ANOVA

Ketentuan :

Jika Fhitung > Ftabet maka $\mathrm{Ha}$ diterima, artinya variabel secara simultan mempunyai pengaruh yang signifikan terhadap variabel independen, Berdasarkan pada tabel 4.48 atas nilai Fhitung sebesar 38,886. Nilai Ftabel dapat dicari dengan persamaan df $1=$ jumlah variabel bebas, artinya df $1=2$, sedangkan df $2=\mathrm{n}-\mathrm{k}-$ 1; (38-2-1); artinya df $2=35$. Dengan menggunakan signifikan 5\% $(0,05)$ dapat dilihat pada tabel F pada kolom 2 baris 35 yaitu 3,27. Berdasarkan hasil dalam perhitungan tersebut maka dapat disimpulkan bahwa Fhitung > Ftabel $(38,886>3,27)$ dan nilai signifikansi $0,000<0,05$ sehingga Ho ditolak dan Ha diterima. Kesimpulan dari diterimanya $\mathrm{Ha}$ adalah nilai koefisien regresi tidak sama nol artinya Variabel Keselamatan Kerja (X1) dan Kesehatan Kerja (X2) berpengaruh secara signifikan dan simultan terhadap Variabel Kinerja Karyawan (Y).

Pada regresi linier sederhana, diperoleh $\mathrm{Y}=4.113+0,850 \mathrm{X} 1$

Dimana :

$\mathrm{Y}=$ Kinerja Karyawan

$\mathrm{X} 1=$ Keselamatan Kerja

Persamaan regresi linear sederhana tersebut mengandung arti bahwa setiap kenaikan nilai pada variabel X1 (Keselamatan Kerja) sebesar 0,850 maka akan diikuti meningkatnya Y (Kinerja Karyawan) sebesar 4,113. Pada koefisien korelasi sederhana (r), diperoleh angka sebesar 0,760 yang berartimenyatakan bahwa kedua variabel tersebut memliki hubungan yang kuat dan linier positifsesuai dengan tingkat kolerasi dan kekuatan hubungan. Pada koefisien Determinasi $\left(\mathrm{r}^{2}\right)$, diperoleh $\mathrm{R}^{2}$ sebesar 0,569. Berarti variabel independen Keselamatan Kerja dapat menjelaskan sebesar 56,9\% terhadap variabel dependen yaitu Kinerja Karyawan sedangkan sisanya $43,1 \%$ dijelaskan oleh variabel lain.

Mengenai rekapitulasi jawaban responden pernyataan Keselamatan Kerja bobot tertinggi adalah pernyataan nomor 6 yaitu Asuransi untuk tenaga kerja yang ada sudah optimal. halini terlihat dari bobot dan hasil dari perhitungan penelitian sebesar 147 (3.87). sedangkan bobot terendah adalah pernyatan nomor 2 yaitu Ketersediaan perlengkapan keselamatan kerja sebagai alat pencegahan sudah memadai, dengan bobot dan hasil penelitian sebesar 135 (3.55). Hal ini menunjukkan sebagian besar pandangan karyawan bahwa ketersediaan perlengkapan keselamatan sebagai alat pencegahan belum memadai. 
Diketahui thitung $6.899>$ tabel 1.688 dan nilai signifikans 0,000 lebih kecil dari 0,05. Yang berarti $\mathrm{H}_{\mathrm{O}}$ ditolak dan $\mathrm{H}_{\mathrm{a}}$ diterima, yang berarti ada pengaruh yang signifikan antara Keselamatan Kerja terhadap Kinerja Karyawan. Hal ini sejalan dengan penelitian (Firmanzah et al., 2017) yang berjudul Pengaruh Keselamatan Kerja dan Kesehatan Kerja Terhadap Kinerja Karyawan (Studi Pada Karyawan PT. PLN (Persero) Area Kediri Distribusi Jawa Timur) tahun 2017 yang menyatakan adanya Pengaruh signifikan antara Keselamatan Kerja terhadap Kinerja Karyawan dan penelitian dari (Saraswati, 2018) yang berjudul Pengaruh Keselamatan Kerja dan Kesehatan kerja Petugas Ground Support Equipment pada PT. Gapura Angkasa Terminal 3 Bandara Soekarno - Hatta tahun 2018 yang menyatakan terdapat pengaruh signifikan antara Keselamatan kerja terhadap Kinerjakaryawan.

Pada Regresi linear sederhana, diperoleh Y $=5,200+0,609$ X2

Dimana :

$\mathrm{Y}+$ Kinerja KaryawanX2 $=$ Kesehatan Kerja

Persamaan regresi linier sederhana tersebut mengandung arti bahwa setiap kenaikan 1 unit nilai pada variabel X2 (Kesehatan Kerja) sebasar 0,648 maka akan dikuti meninkatnya Y (Kinerja Karyawan) sebesar 7,846. Pada koefisien korelasi sederhana (r), diperoleh angka sebesar 0,770 menyatakan kuat positif sesuai dengan tabel tingkat korelasi dan kekuatan hubungan. Pada Koefisien Determinasi $\left(\mathrm{r}^{2}\right)$, diperoleh $\mathrm{R}^{2}$ sebesar 0,778. Berarti variabel independen Kesehatan Kerja dapat menjelaskan sebesar 60,5\% terhadap variabel dependen yaituKinerja Karyawan sedangkan sisanya 39,5\% dijelaskan oleh variabel lain.

Mengenai rekapitulasi jawaban responden pernyataan responden pernyataan Kesehatan Kerja diketahui bobot tertinggi adalah pernyataan nomor 5 yaitu sarana olahraga sudah memadai, hal ini terlihat dari bobot dan hasil dari perhitungan penelitian sebesar 155 (4.08), sedangkan bobot terendah adalah pernyataan nomor 8 yaitu karyawan memperhatikan makanan yang bergizi untuk dikonsumsi, dengan bobot dan hasil penelitian sebesar 131 (3.45). Hal ini membuktikan bahwa masih banyak karyawan yang belum memperhatikan makanan yang bergizi untuk dikonsumsi yang tentunya akan berpengaruh pada kesehatan kerja karyawan.

Pada Uji t, dapat diketahui thitung 7,486 > ttabel 1,688 dan nilai signifikansi 0,000 lebih kecildari 0,05. Yang berarti $\mathrm{H}_{\mathrm{O}}$ ditolak dan $\mathrm{Ha}_{\mathrm{a}}$ diterima, yang berarti ada pengaruh yang signifikan antara Kesehatan Kerja terhadap Kinerja. Hal ini sesuai dengan penelitian (Firmanzah et al., 2017) yang berjudul Pengaruh Keselamatan Kerja dan Kesehatan Kerja Terhadap Kinerja Karyawan (Studi Pada Karyawan PT. PLN (Persero) Area Kediri Distribusi Jawa Timur) tahun 2017 yang menyatakan adanya Pengaruh signifikan antara Kesehatan Kerja terhadap Kinerja Karyawan dan Penelitian (Saraswati, 2018) yang berjudul Pengaruh Keselamatan Kerja dan Kesehatan kerja Petugas Ground Support Equipment pada PT. Gapura Angkasa Terminal 3 Bandara Soekarno - Hatta tahun 2018 yang menyatakan terdapat pengaruh signifikan antara Kesehatan Kerja terhadap Kinerjakaryawan.

Pada Regresi Linear Berganda

$\mathrm{Y}=2,362+0,448 \mathrm{X} 1+0,405 \mathrm{X} 2$

Dimana :

$\mathrm{Y}=$ Kinerja Karyawan

$\mathrm{X} 1=$ Keselamatan Kerja

$\mathrm{X} 2$ = Kesehatan Kerja

Persamaan regresi linear berganda tersebut mengandung arti bahwa setiap kenaikan skor penerapan pada variabel X1 (Keselamatan Kerja) sebesar 0,448 maka akan diikuti meningkatnya Y (Kinerja ). Setiap terjadi kenaikan 1 unit skor untuk variabel X2 (kesehatankerja) sebesar 0,405 akan diikuti dengan meningkatnya Y (Kinerja Karyawan). Dari persamaan diatas maka nilai Y akan menjadi 2,362.

Pada koefisien kolerasi berganda (r), diperoleh angka sebesar 0,824 menyatakan kuat positif sesuai dengan tabel tingkat korelasi dan kekuatan dan linear hubungan. Pada Koefisien Determinasi $\left(\mathrm{r}^{2}\right)$, diperoleh $\mathrm{R}^{2}$ sebesar 0,678. Berarti variabel independenmenjelaskan sebesar $67,8 \%$ terhadap variabel dependen, sedangkan sisanya $33,2 \%$ dijelaskan oleh variabel lain. 
Mengenai rekapitulasi jawaban responden pernyataan Kinerja diketahui bobot tertinggi adalah pernyataan nomor 4 yaitu mampu menyelesaikan beberapa pekerjaan sesuai perintah, hal ini terlihat dari bobot dan hasil perhitungan penelitian sebesar 146 (3.84). sedangkan bobot terendah adalah pernyataan nomor 2 yaitu menyelesaikan tugas / pekerjaan sesuai dengan batas waktu yang telah diberikan, pernyataan 6 yaitu selalu mengecek ulang hasil pekerjaan yang sudah dikerjakan dan 8 yaitu memenuhi peraturan perusahaan, dengan bobot dan hasil penelitian masing - masing sebesar 136 (3.58). Hal ini membuktikan bahwa masih banyak karyawan PT. Angkasa Pura Kargo unit regulated agentyang belum dapat mengerjakan tugas sesuai dengan batas waktu yang diberikan, tidak mengecek ulang hasil pekerjaan dan tidak memenuhi peraturan perusahaan.

Pada Uji F, dapat disimpulkan bahwa Fhitung 38,886 > Ftabel 3,27 sedangkan H0 ditolak danHa diterima, yang berarti ada pengaruh yang signifikan antara keselamatan kerja dan kesehatan kerja terhadap Kinerja Karyawan. Hal ini sesuai dengan hasil penelitian (Saraswati, 2018) yang berjudul Pengaruh Keselamatan Kerja dan Kesehatan kerja PetugasGround Support Equipment pada PT. Gapura Angkasa Terminal 3 Bandara Soekarno - Hatta tahun 2018 yang menyatakan terdapat pengaruh signifikan antara Keselamatan kerja dan Kesehatan Kerja terhadap Kinerja karyawan dan penelitian (Firmanzah et al., 2017) yang berjudul Pengaruh Keselamatan Kerja dan Kesehatan Kerja Terhadap Kinerja Karyawan (Studi Pada Karyawan PT. PLN (Persero) Area Kediri Distribusi Jawa Timur) tahun 2017 yang menyatakan adanya Pengaruh signifikan antara Keselamatan Kerja dan Kesehatan Kerja terhadap Kinerja Karyawan.

\section{KESIMPLAN DAN SARAN}

Berdasarkan hasil pembahasan mengenai Pengaruh Keselamatan Kerja dan Kesehatan Kerja Terhadap Kinerja Karyawan Unit Regulated Agent di PT. Angkasa Pura Kargo, maka dapat diambil kesimpulan sebagai berikut :

1. Adanya pengaruh Keselamatan Kerja terhadap kinerja karyawan yaitu setiap kenaikan 1 unit nilai pada variabel X1 (Keselamatan Kerja) sebesar 0,850 maka akan diikuti meningkatnya Y (kinerja Karyawan) sebesar 4,113. Analisis koefisien korelasi, nilai r (korelasi) sebesar 0,760 maka Keselamatan Kerja memiliki hubungan yang "kuat" terhadap kinerja karyawan. Serta hasil koefisien determinasi menunjukan bahwa Keselamatan Kerja merupakan salah satu faktor yang memberikan pengaruh sebesar 56,9\%\% Kinerja karyawan, sedangkan 43,1\% dipengaruhi oleh faktor lain. Sehingga hasil uji hipotesis menunjukan Thitung 6,899 > ttabel 1,688 sehingga Ho ditolak dan Ha diterima, yang berarti ada pengaruh yang signifikan antara Keselamatan Kerja terhadap kinerja karyawan. Asuransi untuk tenaga kerja sudah optimal, Hal ini dibuktikan dengan rekapitulasi jawaban responden pernyataan Keselamatan Kerja bobot tertinggi adalah pernyataan nomor 6 hal ini terlihat dari bobot dan hasil dari perhitungan penelitian sebesar 147 (3.87).

2. Adanya pengaruh kesehatan kerja terhadap kinerja karyawan yaitu setiap kenaikan 1 unit nilai pada variabel X2 (Kesehatan Kerja) sebesar 0,648 maka akan diikuti meningkatnya Y (Kinerja Karyawan) sebesar 7,846. Analisis koefisien korelasi, nilai r (korelasi) sebesar 0,770 maka kesehatan kerja memiliki hubungan yang "kuat" terhadap kinerja karyawan. Serta hasil koefisien determinasi menujukan bahwa kesehatan kerja merupakan salah satu faktor yang memberikan pengaruh sebesar 60,5\% kinerja karyawan sedangkan 39,5\% dipengaruhi oleh faktor lain. Sehingga uji hipotesis menunjukan thitung 7,486 > ttabel 1,688 sehingga Ho ditolak dan Ha diterima yang berarti ada pengaruh yang signifikan antara kesehatan kerja terhadap kinerja karyawan. Sarana Olahraga sudah memadai, hal ini dibuktikan dengan rekapitulasi jawaban responden. Pada pernyataan Kesehatan Kerja diketahui bobot tertinggi adalah pernyataan nomor 5 hal ini terlihat dari bobot dan hasil dari perhitungan penelitian sebesar 155 (4.08).

3. Adanya pengaruh keselamatan kerja dan kesehatan kerja terhadap kinerja karyawan yaitu setiap kenaikan skor pada variabel X1 (keselamatan kerja) sebesar 0,448 Maka akan diikuti meningkatnya Y (Kinerja Karyawan). Setiap terjadi kenaikan 1 unit skor untuk variabel X2 (kesehatan kerja) sebesar 0,405 akan diikuti dengan meningkatnya Y (Kinerja Karyawan). Dari persamaan diatas, maka nilai Y akan menjadi 2,362. Analisis koefisien kolerasi berganda, nilai r (korelasi)sebesar 0,824 maka keselamatan kerja dan kesehatan kerja memiliki hubungan yang "kuat" terhadap kinerja karyawan. Serta hasil koefisien determinasi menunjukan bahwa Keselamatan kerja dan kesehatan kerja merupakan salah satu faktor yang memberikan pengaruh sebesar 67,8\% terhadap kinerja karyawan, sedangkan 33,2\% dipengaruhioleh fasktor lain. Sehingga hasil uji hipotesis menunjukan Fhitung 38,886 > Ftabel 3,27 sehingga Ho = ditolak 
dan $\mathrm{Ha}=$ diterima, artinya variabel keselamatan kerja (x1) dan kesehatan kerja (X2) secara simultan mempunyai pengaruh yang signifikan terhadap Kinerja Karyawan (Y). Sebagian besar karyawan mampu menyelesaikan beberapa pekerjaan sesuai perintah, hal ini dibuktikan dengan rekapitulasi jawaban responden pernyataan Kinerja diketahui bobot tertinggi adalah pernyataan nomor 4, hal ini terlihat dari bobot dan hasil perhitungan penelitian sebesar $146(3.84)$.

\section{Daftar Pustaka}

Erickson. (2014). Kesehatan Kerja. ALFABETA.

Firmanzah, A., Hamid, D., \& Djudi, Mo. (2017). Pengaruh Keselamatan dan Kesehatan Kerja terhadap Kinerja Karyawan (studi pada Karyawan PT. PLN (persero) Area Kediri Distribusi.

Hasibuan, M. (2019). MANAJEMEN SUMBER DAYA MANUSIA (20th ed.).

Kasmir. (2016). Manajemen Sumber Daya Manusia. Rajagrafindo Persada.

Mangkunegara, A. P. (2017). Evaluasi Kinerja SDM. Evaluasi Kinerja SDM, 9.

Mangkunegara, A. prabu. (2017). MANAJEMEN SUMBER DAYA MANUSIA PERUSAHAAN (14th ed.). PT REMAJA ROSDAKARYA.

Manullang. (2008). Keselamatan Kerja dan Kesehatan Kerja. PT. Grafindo Persada.

Moenir. (2018). MANAJEMEN PELAYANAN UMUM DI INDONESIA (11th ed.). BUMI AKSARA.

Saraswati, R. (2018). Pengaruh Keselamatan dan Kesehatan Kerja terhadap Kinerja Petugas Ground Handling Equipment pada PT. Gapura Angkasa pada terminal 3 Bandar Udara Internasional Soekarno-Hatta tahun 2018 